\title{
Louis Dupree: A Tribute
}

\author{
by M. Nazif Shahrani
}

Afghanistan's natural and human resources have been devastated by the more than a decade-long direct and indirect military aggression by the Soviet Union against her small, traditionally nonaligned, Muslim neighbouring state in Central Asia. The displacement of over five million Afghans as refugees in Pakistan and Iran, and another two and a half million displaced from rural villages and small provincial towns into the capital, Kabul, and a few larger urban centres inside the country, is but one consequence of the war of resistance by the peoples of Afghanistan. The Soviets have now withdrawn their troops from Afghanistan, but their aggression against the people of Afghanistan and their colonialist policy of domination continues unabated. Their war by proxy goes on with greater intensity, using new and more lethal weapons. The Russians have unleashed a powerful international media campaign to present their withdrawal from Afghanistan as evidence of a change of policy and proof of their peaceful intentions in Afghanistan. In reality, however, the Soviets have introduced new and more sophisticated means of pursuing the goals they could not accomplish by direct intervention.

During the entire struggle, Afghans have fought bravely and recorded many important military victories against their powerful enemies. However, they have failed to achieve the same level of success in effectively presenting their case to the world community through the media so as to properly expose the moral bankruptcy of the Soviet policies in Afghanistan. With the premature demise of Louis Dupree, a strong and very effective voice of the Afghan cause in the scholarly as well as journalistic community, the difficulties of maintaining strong and powerful media campaigns may be further aggravated.

Professor Dupree, often referred to in academic circles as the Dean of Afghanistan Studies, was a pioneer in the field. His research and publishing career on Afghanistan spanned some forty years, beginning in 1949, when he participated in an archaeological excavation in Southwestern Afghanistan as a Harvard graduate student, until his death, due to lung cancer, on March 21, 1989. Louis Dupree, a trained archaeologist, directed the American Archaeological Mission in Afghanistan (1959-1971), and was also a member of the American Universities Field Staff (1959-1983) covering Afghanistan and Pakistan. In his capacity as an AUFS researcher and teacher he spent many years living in Afghanistan, travelling to the most remote parts of the country, studying and reporting on many aspects of the contemporary heterogeneous Afghan society, culture, economy, and politics. His monumental and encyclopaedic book, Afghanistan (Princeton: Princeton University Press, 1973; updated 1980) presents a lasting legacy of his commitment and valuable service to students and researchers for generations to come.

Louis Dupree published tirelessly both in academic journals and the public media, writing on a wide variety of themes, peoples, regions, issues and events of consequence in Afghanistan. As such, all scholars of Afghanistan owe him a significant intellectual debt. Louis's contribution to Afghanistan studies was by no means limited to his published works. His direct personal support, and enthusiastic encouragement of all researchers interested in Afghanistan studies, especially Afghan students and scholars, was unparalleled. He was a jovial, genial, energetic and provocative scholar with an uncommon sense of dedication to "his friends, the Afghans" and to Afghan affairs. He shared the grief of the Afghan nation during the last decade of Soviet intervention, and he never faltered in the belief that the Afghans would not submit to brute force. He continued to study Afghanistan, together with his wife and research companion Nancy Hatch Dupree; they were intimate observers of the plight of the Afghan refugees in neighbouring Pakistan, and outspoken advocates in the international arena. The fact that just a few weeks before Louis's death the defeated Red Army was in the last phase of its final departure from Afghanistan must have given him some satisfaction. At this critical phase in the struggle for regaining the right of self-determination by the peoples of Afghanistan, the loss of Louis Dupree's active voice in support of the Afghan cause is irreplaceable. However, the jihad must go on without Louis, and the challenge of repatriating and rehabilitating the refugees, and reconstructing and developing Afghanistan must be faced. In this process Louis's knowledge and insights, and his passion for Afghanistan, will be sorely missed.

M. Nazif Shahrani is an Associate Professor of Anthropology and Middle Eastern Studies at UCLA, and a Co-Director of the Centre for Asian Studies in Islamabad, Pakistan.

\section{Canadian Foreign Policy}

In 1980, Canada de-recognized the Kabul government. In 1988, External Affairs, in a letter to Human Concern International stated: "Canada does not recognize the present government [of Afghanistan] as it has no legitimacy". In 1986 and 1987, at annual United Nations debates on Afghanistan, then Canadian ambassador Stephen Lewis gave extremely strong speeches, using numerous human rights reports. He quoted from the UN's own Special Rapporteur on Human Rights in Afghanistan about the "evidence that genocide has been committed against the Afghan people by the combined forces of the Democratic Republic of Afghanistan and the Soviet Union." 